\title{
Ventricular septal intramyocardial dissection after cardiac tumor excision
}

\author{
Gang Wang ${ }^{1}$, Aijun Liu $^{2}$, Gengxu Zhou ${ }^{1}$, and Zhichun Feng ${ }^{1}$ \\ ${ }^{1}$ Southern Medical University \\ ${ }^{2}$ Bayi Children's Hospital
}

January 24, 2022

\begin{abstract}
Intramyocardial dissection following cardiac tumor excision is uncommon. The evidence available is limited to few case reports.

${ }^{1}$ Herein,we report an infant with large cardiac fibrosarcoma arising from the interventricular septum and underwent surgical excision. Postoperative echocardiography revealed a cystic dissection located in the interventricular septum with residual shunts within the ventricular chambers. we performed conservative strategy due to the high surgical risk, difficulty of interventional therapy and hemodynamic stability.
\end{abstract}

\section{Hosted file}

main document.docx available at https://authorea.com/users/443739/articles/553906ventricular-septal-intramyocardial-dissection-after-cardiac-tumor-excision

\section{Hosted file}

figures.docx available at https://authorea.com/users/443739/articles/553906-ventricularseptal-intramyocardial-dissection-after-cardiac-tumor-excision 